\title{
Errors in medicine administration - profile of medicines: knowing and preventing*
}

\author{
Perfil de medicamentos envolvidos com erros de administração: conhecer para prevenir
}

Perfil de medicamentos envueltos en errores de administración: conocer para prevenir

\section{Adriano Max Moreira Reis ${ }^{1}$, Tatiane Cristina Marques ${ }^{2}$, Simone Perufo Opitz ${ }^{3}$, Ana Elisa Bauer de Camargo Silva ${ }^{4}$, Fernanda Raphael Escobar Gimenes ${ }^{5}$, Thalyta Cardoso Alux Teixeira ${ }^{6}$, Rhanna Emanuela Fontenele Lima $^{7}$, Silvia Helena De Bortoli Cassiani ${ }^{8}$}

\begin{abstract}
Objectives: To describe the pharmacological characteristics of medicines involved in administration errors and determine the frequency of errors with potentially dangerous medicines and low therapeutic index, in clinical units of five teaching hospitals, in Brazil. Methods: Multicentric study, descriptive and exploratory, using the non-participant observation technique (during the administration of 4958 doses of medicines) and the anatomical therapeutic chemical classification (ATC). Results: Of that total, 1500 administration errors were identified (30.3\%). The administration of pharmacological groups - ATC (cardiovascular system, nervous system, alimentary tract and metabolism system and anti-infectives for systemic use) showed a higher frequency of errors. In $13.0 \%$ of errors were involved potentially dangerous medicines and in 12.2\% medicines with low therapeutic index. Conclusion: The knowledge of the pharmacological profile could be an important strategy to be used in the prevention medication errors in health institutions.
\end{abstract}

Keywords: Medication errors; Medication systems hospital

\section{RESUMO}

Objetivos: Descrever as características farmacológicas dos medicamentos envolvidos em erros de administração e determinar a frequência desses erros com medicamentos potencialmente perigosos e de baixo índice terapêutico em unidades de clínica médica de cinco hospitais de ensino brasileiros. Métodos: Estudo multicêntrico, descritivo/exploratório utilizando a técnica de observação não participante durante a administração de 4958 doses de medicamentos e a classificação anatômica terapêutica química (ATC). Resultados: Dentre esse total, foram identificados 1500 erros de administração de medicamentos (30,3\%). A administração dos fármacos dos grupos ATC - sistema cardiovascular, sistema nervoso, trato alimentar e metabolismo e antinfecciosos de uso sistêmico apresentou maior frequência de erros. Em $13,0 \%$ dos erros estavam envolvidos medicamentos potencialmente perigosos e em $12,2 \%$ medicamentos de baixo índice terapêutico. Conclusão: O conhecimento do perfil farmacológico pode ser uma importante estratégia a ser utilizada na prevenção de erros de medicação em instituições de saúde.

Descritores: Erros de medicação; Sistemas de medicação no hospital

\section{RESUMEN}

Objetivos: Describir las características farmacológicas de los medicamentos envueltos en errores de administración y determinar la frecuencia de esos errores en medicamentos potencialmente peligrosos y en los de bajo índice terapéutico, en unidades de clínica médica de cinco hospitales de enseñanza brasileños. Métodos: Estudio multicéntrico, descriptivo-exploratorio utilizando la técnica de observación no participante (durante la administración de 4.958 dosis de medicamentos) y la clasificación anatómica terapéutica química (ATC). Resultados: Fueron identificados 1500 errores de administración de medicamentos (30,3\%). La administración de los fármacos de los grupos ATC (sistema cardiovascular, sistema nervioso, sistema digestivo y metabolismo, y, anti-infecciosos) de uso sistémico presentó mayor frecuencia de errores. En 13,0\% de los errores estaban envueltos medicamentos potencialmente peligrosos y en 12,2\% medicamentos de bajo índice terapéutico. Conclusión: El conocimiento del perfil farmacológico puede ser una importante estrategia para prevenir los errores de medicación en las instituciones de salud.

Descriptores: Errores de medicación; Sistemas de medicación en hospital

* Research developed at the University of São Paulo at Ribeirão Preto College of Nursing - USP - Ribeirão Preto (SP), Brazil.

${ }^{1}$ Ph.D. in Sciences. Adjunct Professor at School of Pharmacy, Federal University of Minas Gerais - UFMG, Belo Horizonte (MG), Brazil.

${ }^{2}$ Pharmacist. M.Sc. in Fundamental Nursing at University of São Paulo at Ribeirão Preto College of Nursing - USP - Ribeirão Preto (SP), Brazil.

${ }^{3}$ Ph.D. in Nursing. Adjunct Professor at Federal University of Acre - UFAC, Rio Branco (AC), Brazil.

${ }^{4}$ Ph.D. in Nursing. Adjunct Professor at School of Nursing, Federal University of Goiás - UFG, Goiânia (GO), Brazil.

${ }_{5}^{5}$ Faculty in Nursing Course at Camilo Castelo Branco University - UNICASTELO, Descalvado (SP), Brazil. Ph.D. student in Fundamental Nursing at University of São Paulo at Ribeirão Preto College of Nursing - USP - Ribeirão Preto (SP), Brazil.

6,7 Ph.D. student in Fundamental Nursing at University of São Paulo at Ribeirão Preto College of Nursing - USP - Ribeirão Preto (SP), Brazil.

${ }^{8}$ Full Professor at University of São Paulo at Ribeirão Preto College of Nursing - USP - Ribeirão Preto (SP), Brazil. 


\section{INTRODUCTION}

The report "To Err is Human", published by the Institute of Medicine (IOM) in 2000, caused great repercussion in the media and among health professionals, as it evoked the problem of adverse events in health services ${ }^{(1)}$. Since then, patient and care safety have become a source of concern in different countries ${ }^{(2)}$.

The second IOM report, called "Crossing the Quality Chasm a New Health System for the 21st Century", was published in 2001 and stood out because it alerted health professionals to the frequency of adverse events and the systemic nature of their determining factors. Besides emphasizing the contribution of adverse events to the increase in health costs and prevention as an essential tool to expand patient safety, the report also demonstrated that adverse drug event (ADE) are one of the main reasons for patient damage ${ }^{(3)}$.

Medication errors can be prevented, are related to the drugs use process and can cause patient damage or not. ADE, on the other hand, are characterized by the presence of damage, deriving from an adverse reaction or medication error $^{(4)}$.

Hence, concerns with ADE are increasing, mainly after the dissemination of epidemiological studies that estimate that each patient hospitalized in North American hospitals is subject to one medication error per day and that, every year, in hospitals, at least 400,000 drugs-related avoidable adverse events occur in hospitals $^{(5)}$.

Medication errors in the medication administration process have been identified in Brazilian and international research. The frequency of errors during the medication administration process detected in these studies ranges from $14.9 \%$ to $59.5 \%{ }^{(6-9)}$. This variation in administration error frequencies is due to differences in the research methods used, in health service characteristics and in the adopted error typology.

The range of ADE for public health culminated in the IOM's most recent publication called "Preventing medication errors", which presents a series of recommendations to improve different medication system processes ${ }^{(5)}$. The recommendations address strategic issues to increase the safety of medication use, covering specific medication administration issues.

Medication errors are systemic and multiple determining factors are involved. Among factors related to drugs contributing to administration errors, the following stand out: the administration route, required administration complexity, pharmacological characteristics and the nursing team's knowledge on the drug ${ }^{(10-12)}$.

In this context, this research aimed to describe the pharmacological characteristics of drugs involved in administration errors and to determine the frequency of these errors involving high-alert medication (HAM) and narrow therapeutic index drugs (NTID) at medical clinical units of five Brazilian teaching hospitals.

\section{METHODS}

This multicenter exploratory research aimed to obtain detailed information about the medication error variable in Brazilian hospitals, with a view to determining the frequency and factors associated with the occurrence of this event. Error was considered as any discrepancy between what was prescribed and what the nursing team administered to the patient. In this paper, data about the pharmacological profile of the drugs involved in administration errors are presented.

The research was developed at medical clinical units of five Brazilian public teaching hospitals in the North, Northeast, Southeast and Central-West of Brazil. The medical clinical unit was selected because it offers beds to patients with chronicdegenerative diseases, who usually consume many drugs over long period, covering different therapeutic classes.

For data collection, direct non-participant observation was performed in accordance with an observation script. After a twenty-hour training, fifteen research auxiliaries observed the activities of nursing professionals responsible for drugs administration during 30 days, including the three shifts (morning, afternoon and night). Three research auxiliaries were designated to each hospital and data were collected during the same period at all research hospitals. The analysis unit was the administered drug. Next, the data collected through observation were confronted with the prescription to verify whether any discrepancy occurred, considering patient, time, administration route, drug and dosage. Patient safety experts validated the data collection instrument and the observation script.

This research was carried out after authorization was obtained from the research hospital boards and approval from the respective Research Ethics Committees, according to protocols HCRP No 12216/2004, CEP/UNIFESP/HSP No 1413/04, CEPMHA/ HC/UFG No 096/04, Letter No 919-2004/GD and FUNDHACRE Protocol No 174/2005. Before data collection, the research subjects received clarifications about the study and all participants signed the Free and Informed Consent Term.

Medication errors were classified according to the American Society of Health System Pharmacists' typology: dose error, unauthorized drug error, route error, patient error and time error $^{(13)}$. Time error was considered as the situation in which the drug was administered more than 60 minutes before or after the administration time defined on the prescription or administration plan elaborated by the nurse or nursing technician.

The pharmacological classification was performed in accordance with the anatomical therapeutic chemical (ATC) system of the WHO Collaborating Centre for Drug Statistics Methodology, an entity affiliated with the World Health Organization ${ }^{(14)}$. NTID were identified in a tertiary pharmacotherapy reference source and in the Brazilian Health Surveillance Agency's NTID list ${ }^{(15-16)}$. HAM were classified according to the Institute for Safe Medication Practice (ISMP) $^{(17)}$.

The collected data were transferred to an EPIDATA 3.1 database. Database consistency was validated and checked through double typing. SPSS 11.5 software was used for statistical analysis, through univariate descriptive analysis with absolute and relative frequencies.

\section{RESULTS}

In total, 4958 administered drugs doses were observed, and 
1500 errors were detected, that is, $30.3 \%$ of errors during medication administration in this research. Error types were distributed as follows: patient error $(7-0.5 \%)$, route error $(92-$ $6.1 \%)$, unauthorized drug error $(26-1.7 \%)$, dose error $(215-$ $14.4 \%)$ and time error $(1160-77.3 \%)$.

Table 1 shows the distribution of drug administration errors according to pharmaceutical dosage form, most frequently involving drugs for parenteral use (48.5\%).

Table 1 - Drug administration errors, according to pharmaceutical dosage form, at medical clinical units of public teaching hospitals, Brazil, 2006

\begin{tabular}{lrr}
\hline Pharmaceutical dosage Form & N & $\mathbf{0 \%}$ \\
\hline For parenteral use & 728 & 48.5 \\
Solid for oral use & 626 & 41.8 \\
For inhalatory use & 74 & 4.9 \\
Liquid for oral use & 65 & 4.3 \\
For topical use & 4 & 0.3 \\
For ophthalmic use & 3 & 0.2 \\
\hline Total & 1500 & 100.0 \\
\hline
\end{tabular}

The ATC I classification evidences that group C (21.6\%), N $(19.5 \%), \mathrm{A}(19.1 \%)$ and $\mathrm{J}(18.5 \%)$ drugs were most involved in errors, as shown in Table 2.

Table 2 - Drug administration errors, according to level I anatomical therapeutic chemical (ATC) classification at medical clinical units of public teaching hospitals, Brazil, 2006

\begin{tabular}{lrr}
\hline $\begin{array}{l}\text { Anatomical therapeutic chemical } \\
\text { group }\end{array}$ & N & \% \\
\hline C - Cardiovascular system & 324 & 21.6 \\
N - Nervous system & 292 & 19.5 \\
A - Alimentary tract and metabolism & 287 & 19.1 \\
J - Anti-infectives for systemic use & 277 & 18.5 \\
B - Blood and blood-forming organs & 136 & 9.0 \\
R - Respiratory system & 94 & 6.3 \\
H - Systemic hormonal preparations, & 64 & 4.3 \\
excluding sex hormones and insulins & & \\
M - Musculo-skeletal system & 8 & 0.6 \\
P - Antiparasitic products, insecticides & 8 & 0.6 \\
and repellents & & \\
L - Antineoplastic and & 4 & 0.3 \\
immunomodulating agents & & \\
S - Sensory organs & 3 & 0.2 \\
G - Genito-urinary system and sex & 2 & 0.1 \\
hormones & & \\
V - Various & 1 & 0.1 \\
\hline Total & 1500 & 100.0 \\
\hline
\end{tabular}

The HAM identified in this research and the respective error frequencies are presented in Table 3, corresponding to $13.0 \%$ of drugs involved in administration errors.

NTID errors corresponded to $12.2 \%$ and heparin, vancomycin, clindamycin, carbamazepine and phenitoin were the most frequent drugs involved in administration errors (Table 4).
Table 3 - High - alert medication (HAM) involved in administration errors at medical clinical units of public teaching hospitals, Brazil, 2006

\begin{tabular}{lrr}
\hline High- alert medication & $\mathbf{N}$ & $\mathbf{0}$ \\
\hline Injectable heparin & 65 & 33.3 \\
Injectable tram adol & 42 & 21.4 \\
Injectable insulin & 25 & 12.7 \\
Injectable enoxaparin & 11 & 5.5 \\
Morphine tablet & 11 & 5.5 \\
Paracetam ol + codein tablet & 10 & 5.1 \\
Tram adol capsule & 7 & 3.6 \\
Injectable morphine & 6 & 3.1 \\
Metphormin tablet & 4 & 2.1 \\
Injectable potassium chloride & 3 & 1.5 \\
Warfarin tablet & 3 & 1.5 \\
Injectable glucose 50\% & 3 & 1.5 \\
Injectable pethidine & 2 & 1.0 \\
Injectable sodium chloride & 1 & 0.4 \\
Glibenclamide tablet & 1 & 0.4 \\
Injectable magnesium sulfate & 1 & 0.4 \\
\hline Total & 195 & 100.0 \\
\hline
\end{tabular}

Table 4 - Narrow therapeutic index drugs (NTID) involved in administration errors occurred in medical clinical units of public teaching hospitals, Brazil, 2006

\begin{tabular}{lrr}
\hline Narrow therapeutic index drugs & N & $\mathbf{0}$ \\
\hline Injectable heparin & 65 & 35.5 \\
Injectable vancomycin & 27 & 14.8 \\
Injectable clindamycin & 24 & 13.1 \\
Carbamazepine tablet & 13 & 7.1 \\
Injectable phenytoin & 13 & 7.1 \\
Phenytoin tablet & 9 & 4.9 \\
Clindamycin capsule & 6 & 3.3 \\
Injectable aminophylline & 5 & 2.8 \\
Injectable potassium chloride & 3 & 1.7 \\
Injectable gen tamicin & 3 & 1.7 \\
Warfarin tablet & 3 & 1.7 \\
Injectable amikacin & 2 & 1.1 \\
Injectable amphotericin B & 2 & 1.1 \\
Levothyroxine tablet & 2 & 1.1 \\
Valproic acid capsule & 1 & 0.5 \\
Clindamycin oral solution & 1 & 0.5 \\
Clonidine tablet & 1 & 0.5 \\
Injectable Phenobarbital & 1 & 0.5 \\
Phenobarbital tablet & 1 & 0.5 \\
Levodopa + carbidopa tablet & 1 & 0.5 \\
\hline Total & 183 & 100.0 \\
\hline
\end{tabular}

\section{DISCUSSION}

The medication administration error frequency of $30.3 \%$ found in this research can significantly contribute to knowledge about the medication usage safety scenario in Brazilian hospitals. These data related to hospitals from the North, Northeast, Southeast and Central-West and the identified error percentage is similar to international and Brazilian research ${ }^{(6-9)}$. This result reflects the need to improve medication systems in Brazilian 
hospitals, reconsidering subsystems, reducing steps and simplifying processes with a view to decreasing medication errors $^{(18)}$. This strategy is important because medication errors should be addressed in a systemic perspective that permits evidencing failures in different subsystems' processes. This makes it possible to put in practice improvements and decrease the occurrence of these events. It should be highlighted though that, in order to achieve effective results in intervention plans, it is essential for prescription and administration processes to receive special attention ${ }^{(10-11)}$. Thus, the identification of drugs and other factors associated with administration errors will also contribute to the elaboration of action plans.

The distribution of medication errors in terms of pharmaceutical dosage form evidences that drugs for parenteral use, followed by oral use, were most frequently associated with errors, in line with other studies ${ }^{(19-21)}$. Due to its easy access and commodity, the oral route is one of the most used medication administration routes, which explains the high incidence of errors with drugs for oral administration ${ }^{(22)}$.

Pharmaceutical dosage forms can be classified in terms of administration complexity, risk of damage and cost. Intravenous infusion forms are considered the most complex, followed by direct intravenous, intramuscular and subcutaneous administration. Solid and liquid forms for oral use are the least complex according to this classification. According to the classification of risk for patient damage, parenteral forms present more damage and are proportional to their complexity. Oral usage forms, in function of the greater probability of absorption and systemic action, rank third in terms of damage risk. The cost ranking is the same proposed for administration complexity ${ }^{(22)}$. Hence, when establishing the therapeutic plan, prescribers need to be encouraged to use less complex forms, with less damage risk and lower costs, thus minimizing the possibility of errors.

The complexity of the parenteral drug administration process, involving multiple steps, entails a greater need for adjustments and monitoring during the administration process, consequently increasing the risk of errors ${ }^{(19-22)}$. To expand medication administration safety, particularly for parenteral drugs, information technology applied to health should be incorporated through intelligent infusion systems, bar codes, computerized prescriptions and decision support programs ${ }^{(2)}$.

The risk of errors involving oral solid drugs use is high due to their large-scale use in hospitals, and increases when administration through enteral feeding tubes is needed. Medication errors in this condition can jeopardize treatment efficacy and demand important multiprofessional actions to improve the quality and safety of oral drugs administration in patients receiving enteral feeding therapy ${ }^{(23)}$. The pharmacist and nurse should elaborate guidelines to guarantee adequate oral solid drug use in this patient group, avoiding dispensation and administration errors.

The analysis of the level I ATC classification shows that drugs in groups C, N, A and J (Table 2) were the main therapeutic groups related to errors. This result is equivalent to the profile found by other researchers ${ }^{(12,24)}$. The error frequency related to cardiovascular drugs can be explained by the fact that they are related with chronic illnesses, frequent at medical clinical units.
In this research, errors involving group J drugs, which include antimicrobials and other anti-infectives, figured among the most frequent errors. Concerns with medication errors involving antimicrobials are growing in literature, as the inadequate use of this therapeutic class contributes to the appearance of microbial resistance ${ }^{(25)}$. Therefore, under the nurse's supervision, the nursing team needs to be sensitized about this risk and pay more attention to correct drug administration, especially with regard to antimicrobials.

In order to supervise and carry out medication administration activities, nurses need adequate knowledge about pharmacodynamics, pharmacokinetics, administration techniques, adverse drug reactions, drug interactions and therapeutic response monitoring parameters ${ }^{(10-12,24)}$. This knowledge is essential when considering the variety of the therapeutic arsenal available in hospitals, which increases day by day through the incorporation of new therapeutic classes, new pharmaceutical dosage forms and drugs release systems, generating a risk factor for medication errors $^{(12,20)}$. Periodical professional recycling is a strategy that can reduce the divergence between nursing professionals' knowledge and their activities in medication therapy practice ${ }^{(26)}$.

This divergence mainly derives from the lack of pharmacology education applied to care practice. Pharmacokinetics is taught in undergraduate programs without any correlation with medication errors and risks for patient safety. The same is true for the pattern of adverse reactions, the intensity of the pharmacodynamic effect and other relevant pharmacotherapy issues, mainly when involving HAM.

According to the ISMP, although most drugs have a safe therapeutic margin, some drugs inherently entail risks of patient harm in case of errors in the use process. These drugs are called HAM. These are no longer routine errors but, when they occur, they are very severe and can lead to permanent injuries or be lethal ${ }^{(17)}$.

In this research, HAM errors corresponded to $13.0 \%$, and heparin was responsible for a majority (33.3\%). Errors involving tramadol, insulins and enoxaparin were also frequent. Heparin figures among the ten drugs most frequently mentioned in error notifications involving patient damage in the United States. In 2002 , this drug was responsible for $9.5 \%$ of errors that causes patient harm. Between 1999 and 2002 , rates varied between $4.5 \%$ and $5.5 \%$, ranking first in severe error records ${ }^{27}$.

Due to the characteristics of HAM and the conditions in which these drugs are used in hospitals, they are considered of high risk as, when involved in errors, the consequences can be severe. When putting in practice a medication error prevention program, HAM should be one of the priority groups ${ }^{(17)}$. HAM are especially relevant in emergency services and intensive care units, where their use is more frequent.

In medical clinical units, it is important to identify NTID errors, a known risk factor for ADE. Errors involving these drugs, particularly dose errors, can cause patient harm, turning into a cause of hospital admission or extending hospitalization time, mainly in pediatric and elderly age groups ${ }^{(26)}$. The NTID group is large, covering some HAM, some antimicrobials and other drugs, many of which for oral use. These are drugs with a very small difference between therapeutic and toxic concentration, 
demanding careful monitoring of dosage, clinical effects and, sometimes, blood concentrations. The monitoring of blood levels becomes very important for NTID, as the course and intensity of pharmacological action are directly proportional to the concentrations in body fluids.

Dose errors were the second most frequent category in this research. These errors can be related to mistake in mathematical calculations during drug preparations ${ }^{(11-12)}$. In this research, dosage errors are a source of concerning as, at medical clinical units, the hospitalization of geriatric patients is frequent. This age group presents decreased liver and kidney functions, besides decreased metabolism and medication elimination ${ }^{(26)}$.

The security margin for the use of NTID or HAM is small, which is why dosage and time errors involving these types of drugs are a source of concern. NTID can generate an error cascade if errors occur near the day of therapeutic drug monitoring. As a result of a drugs error, the plasma level will not reflect the patient's clinical context, causing the physician to inadequately adjust the dose, which can expose the patient to a new adverse event.

The main determining factors for the high incidence of time errors are probably part of the administration process, such as the nursing team's time planning, which concentrates a large number of drugs in certain periods, generally in the morning. As a result, the timing for drugs that require punctual administration, such as antimicrobials and NTID, is not respected. This situation is generally due to the high demand for activities and procedures at the hospitalization unit during the morning shift. Another factor that can lead to time errors is the inadequate functioning of the hospital pharmacy's drugs distribution system, leading to medication delivery and, consequently, administration delays ${ }^{(20-21,28)}$.

The relation between lack of knowledge and the medication administration error problem is relevant. The administration errors found in this research can partially be explained by this lack of knowledge ${ }^{(24-26)}$. There is an urgent need for actions to improve nursing students' pharmacology education and clinical nursing professionals' recycling.

In health services, the joint elaboration of medication administration manuals by the pharmaceutical and nursing team, including objective pharmacotherapeutic information, has shown to be an efficient strategy to increase medication usage safety ${ }^{(29)}$.

\section{CONCLUSION}

This research presents a panorama of medication errors at medical clinical units in five Brazilian public hospitals, indicating the high error frequency related to drugs for parenteral administration.

HAM and NTID errors identified in this research represent a risk for medication use safety. Therefore, prevention measures should be put in practice for these groups. Preventive actions should be systemic though, covering the different medication system processes. The application of systemic and planned interventions can reduce the complexity of the system and improve the medication usage process, decreasing the number of medication errors.

Expanding the availability of and access to medication information in all medication system processes contributes to improve medication use safety. Moreover, continuing and permanent pharmacotherapy education is very valuable in information and knowledge dissemination to health teams.

The optimization of the drugs administration process significantly affects the reduction of medication errors and also improves nursing care at the institution, directly influencing costs and care quality.

Knowledge is one of the main tools health professionals have at their disposal to guarantee safe and high-quality care to patients. The researchers hope these results will support patient safety plans and the elaboration of pharmacology training programs integrated into health services and teaching institutions' care practice.

\section{ACKNOWLEDGEMENTS}

To the local coordinators of the multicenter project, nurses Flávio Trevisan Fakih and Maria Ludermiler Sabóia Mota, and to the financial support from FAPESP, CNPq and CAPES.

\section{REFERENCES}

1. Kohn LT, Corrigan JM, Donaldson MS, editors. To err is human: building a safer health system. Washington: Institute of Medicine of National Academy of Sciences; 2000. 312p. [cited 2007 Jun 30]. Available from: http://www.nap.edu/catalog.php?record_id=9728.

2. Bates DW. Preventing medication errors: a summary. Am J Health Syst Pharm. 2007;64(14 Suppl 9):S3-9; quiz S24-6. Erratum in: Am J Health Syst Pharm. 2007;64(16):1678.

3. Committee on Quality of Health Care in America, Institute of Medicine. Crossing the quality chasm: a new health system for the 21 st century. Washington: Institute of Medicine of National Academy of Sciences; 2001. 360p. [cited 2007 Jun 30]. Available from: http://www.nap.edu/catalog.php?record_id=10027.

4. Rommers MK, Teepe-Twiss IM, Guchelaar HJ. Preventing adverse drug events in hospital practice: an overview. Pharmacoepidemiol Drug Saf. 2007;16(10):1129-35.
5. Aspden P, Wolcott J, Bootman JL, Cronenwett LR, Committee on Identifying and Preventing Medication Errors. Preventing medication errors: quality chasm series. Washington: Institute of Medicine of National Academy of Sciences; 2007. 480p. [cited 2007 Jun 30]. Available from: http://www.nap.edu/ catalog.php?record_id=11623.

6. Opitz SP. Sistema de medicação: análise dos erros nos processos de preparo e administração de medicamentos em um hospital de ensino. [tese]. Ribeirão Preto: Escola de Enfermagem de Ribeirão Preto da Universidade de São Paulo; 2006.

7. Costa LA. Avaliação da administração de medicamentos em hospital público e privado de Salvador. [dissertação]. Salvador: Faculdade de Medicina da Universidade Federal da Bahia; 2005.

8. Anselmi ML, Peduzzi M, Dos Santos CB. Errors in the administration of intravenous medication in Brazilian hospitals. 
J Clin Nurs. 2007;16(10):1839-47.

9. Maricle K, Whitehead L, Rhodes M. Examining medication errors in a tertiary hospital. J Nurs Care Qual. 2007;22(1):20-7.

10. McBride-Henry K, Foureur M. Medication administration errors: understanding the issues. Aust J Adv Nurs. 2006;23(3):33-41.

11. Fry MM, Dacey C. Factors contributing to incidents in medicine administration. Part 1. Br J Nurs. 2007;16(9):556-8.

12. Tang FI, Sheu SJ, Yu S, Wei IL, Chen CH. Nurses relate the contributing factors involved in medication errors. J Clin Nurs. 2007;16(3):447-57.

13. ASHP guidelines on preventing medication errors in hospitals. Am J Hosp Pharm. 1993;50(2):305-14. Review.

14. World Health Organization Collaborating Centre for Drug Statistics Methodology. Anatomical Therapeutic Chemical (ATC) index with Defined Daily Doses (DDD) 2007 [citado 2007Jun 30]. Disponível em: http://www.whocc.no/atcddd.

15. Klasco RK. (Ed): DRUGDEX ${ }^{\circledR}$ System. Thomson MICROMEDEX [citado 2007 Jun 30]. Disponível em: http:/ / www.periodicos.capes.gov.br.

16. Brasil. Ministério da Saúde. ANVISA. Resolução RDC no 214, de 12 de dezembro de 2006. Dispõe sobre Boas Práticas de Manipulação de Medicamentos para Uso Humano em Farmácias. Diário Oficial da União, Brasília, 2006 [citado 2007 Jun 30]. Disponível em http://legis.anvisa.gov.br/leisref/public/ showAct.php?id=25128\& mode $=$ PRINT_VERSION.

17. Institute for Safe Medication Practices. ISMP's list of high alert medications. [cited 2007 Jun 30]. Available from: http:// www.ismp.org/Tools/highalertmedications.pdf.

18. Cassiani SHB, Miasso AI, Silva AEBC, Fakin FT, Oliveira RC. Aspectos gerais e número de etapas do sistema de medicação de quatro hospitais brasileiros. Rev Latinoam Enferm. 2004;12(5):781-9.

19. Hugles RG, Ortiz E. Medication errors: why they happen, and how they can be prevented. Am J Nurs. 2005;105(3 Suppl):1424; quiz 48-51. Review.
20. Wirtz V, Taxis K, Barber ND. An observational study of intravenous medication errors in the United Kingdom and in Germany. Pharm World Sci. 2003;25(3):104-11.

21. Cousins DH, Sabatier B, Begue D, Schmitt C, Hoppe-Tichy T. Medication errors in intravenous drug preparation and administration: a multicentre audit in the UK, Germany and France. Qual Saf Health Care. 2005;14(3):190-5.

22. Vanderveen T, Lewis SR, Almeida S. Reducing complexity: a strategic approach to optimizing the medication use process for all medications. Patient Saf Qual Healthcare. 2007. [cited 2007 Aug 05]. Available from: http://www.psqh.com/ sepoct $07 /$ complexity.html

23. Van den Bemt PM, Cusell MB, Overbeeke PW, Trommelen M, van Dooren D, Ophorst WR, Egberts AC. Quality improvement of oral medication administration in patients with enteral feeding tubes. Qual Saf Health Care. 2006;15(1):44-7.

24. Wolf ZR, Hicks R, Serembus JF. Characteristics of medication errors made by students during the administration phase: a descriptive study. J Prof Nurs. 2006;22(1):39-51.

25. Hoefel HHK, Lautert L. Administração endovenosa de antibióticos e resistência bacteriana: responsabilidade da enfermagem. Rev Eletrônica Enferm. 2006;8(3):441-9.

26. Otero-López MJ, Alonso-Hernández P, Maderuelo-Fernandez JA, Garrido-Corro B, Domínguez-Gil A, Sánchez-Rodríguez A. Acontecimientos adversos prevenibles causados por medicamentos en pacientes hospitalizados. Med Clin (Barc). 2006;126(3):81-7.

27. Niccolai CS, Hicks RW, Oertel L, Francis JL; Heparin Consensus Group. Unfractionated heparin: focus on a high-alert drug. Pharmacotherapy. 2004;24(8 Pt 2):146S-155S. Review.

28. Silva AEBC, Cassiani SHB, Miasso AI, Opits SP. Problemas na comunicação: uma possível causa de erros de medicação. Acta Paul Enferm. 2007;20(3):272-6.

29. Bucknall TK. Implementing guidelines to improve medication safety for hospitalised patients: experiences from Western Health, Australia. Worldviews Evid Based Nurs. 2007;4(1):51-3. 